Rev. Biol. Trop., 48(2/3): 629-642, 2000

www.ucr.ac.cr www.ots.ac.cr www.ots.duke.edu

\title{
The effects of food presentation and microhabitat upon resource monopoly in a ground-foraging ant (Hymenoptera: Formicidae) community
}

Terrence P. McGlynn ${ }^{1}$ and S. Eben Kirksey ${ }^{2}$

1 University of San Diego. Department of Biology. 5998 Alcalá Park. San Diego, CA 92110 USA.

email: tmcglynn@acusd.edu

2 Division of Natural Sciences. New College of the University of South Florida. 5700 North Tamiami Trail, box 361, Sarasota, Florida 34243 USA

Received 6-IV-1999. Corrected 11-II-2000. Accepted 8-III-2000.

\begin{abstract}
In Neotropical wet forests several species of omnivorous, resource-defending ants, live and forage in close proximity to one another. Although the forest floor is heterogeneous in microhabitat and food quantity, little is known about the impact of microhabitat and food variation upon resource monopoly among ants. We investigated how food type and microhabitat influence food monopoly in resource-defending ants in old-growth tropical wet forest in the Caribbean lowlands of Costa Rica. We measured several microhabitat characteristics at 66 points in a 0.5 hectare plot, and baited each point with two categories of tuna bait. These baits were presented in "split" and "clumped" arrangements. We measured the frequency of bait monopoly by a single species, as well as the number of recruited ant foragers at a bait. Out of five common species, two (Wasmannia auropunctata and Pheidole simonsi) more frequently monopolized one bait type over the other, and one ( $P$. simonsi) recruited more ants to the split baits. We then considered the recruitment response by all ant species in the community. We found that the frequency of monopoly, sharing, and the absence of ants at a given point in the rainforest differed with bait type. The frequency of monopoly was associated with microhabitat type in two out of eight microhabitat variables (leaf litter depth and palms); variation in two other types (canopy tree distance and leafcutter ant trails) was associated with changes in forager number. In at least two, ant species, food presentation affected monopoly at baits; among all resource-defending ants, the microhabitats where ants foraged for food and the type of food located determined in part the frequency of monopoly and the number of foragers at the food item. These results suggest that the location and presentation of food items determines in part which ant species will utilize the resource.
\end{abstract}

Key words: Competition, recruitment, food presentation, ant, foraging behavior, Wasmannia auropunctata, Pheidole, microhabitat.

In ants, food monopoly may play a major role in structuring communities (Savolainen and Vespalainen 1988, Hölldobler and Wilson 1990, Andersen and Patel 1994, Gordon and Kulig 1996). The monopoly of food resources is an important measure of competition among ants species (Andersen 1992; Andersen and Patel 1994, Tennant 1994). Among ants, the frequency of monopoly at food items is determined by preference for the food item, as well as microhabitats where these ants forage for food. Several studies have shown that ants preferentially recruit to and defend high quality foods that are larger or rich in protein and fat (Bernstein 1975, Davidson 1977, 1978, Adams and Traniello 1981, Traniello 1983, deBiseau et al. 1997). In addition to food quality, microhabitat influences monopoly by ants in Neotropical wet forests by spatially and temporally restricting foraging ranges (Levings 
and Windsor, 1984; Kaspari, 1993a; Perfecto and Vandermeer, 1996).

Food monopoly among ant colonies can occur for two reasons. If more than one colony is feeding at a food item, interspecific interactions can result in the exclusion of competitors. Ants can exclude competitors by using chemical repellents and physical confrontation (reviewed in Holldobler and Wilson 1990).

In a microhabitat where few ants use the food, exploitative competition can result in monopoly because only one colony is taking advantage of the food resource (Davidson 1998).

The sizes and types of ant foods in Neotropical rainforests are highly variable (Janzen 1983); microhabitats are variable in litter depth, plant community composition, and humidity (Janzen 1983, Kaspari 1993a). When an ant colony sends out a forager to search for food, the location and type of food resource will determine in part if she recruits nestmates to that site and whether they will monopolize the food item.

Ant community ecologists have sorted resource-defending ants into functional groups within the context of the community. Hölldobler and Wilson (1990) called resource-defending ants "extirpators" because they excluded other species through interference competition, fighting, and mass recruitment. Andersen $(1995,1998)$ in Australia and North America and Bestelmeyer and Weins (1996) in temperate South America, sorted resource-defending ants into "Dominant Dolichoderines," "Generalized Myrmicines," "Subordinate Camoponotini," and less understood "Cryptic" species. In a European boreal ant community, Savolainen and Vepsalainen (1988) divided resource-defending ants into "territorials" and "encounterers." The scale of the study and the question posed are important in determining which functional group definitions to use in a given study (Andersen 1997b). In this study, species that recruit to food resources and persisted two hours after bait placement are termed as "resourcedefending" ants. In Neotropical leaf litter, resource-defending ants in the genera Pheidole, Solenopsis, and Wasmannia do not defend territories, but nonetheless recruit to and defend food resources close to their nests (Torres 1984, Perfecto 1994). This profile of non-territoriality with high levels of resource defense is consistent with the concepts of "Generalized Myrmicines" (Andersen 1995), and "encounterers" (Savolainen and Vepsalainen 1988).

Although interspecific competition among resource-defending ants in the wet Neotropics has been well studied (Torres 1984, Byrne 1994, Perfecto 1994, Tennant 1994), little is known about how these ants select microhabitats for nesting and foraging. In tropical wet forests, several resource defenders may nest next to one another, sometimes within a single square meter (Byrne 1994). Ant nests and foods are unevenly distributed in leaf litter (Levings and Franks 1982, Janzen 1983, Kaspari, 1996). Within the patchy environment of tropical leaf litter, we do not know where ants look for food; once they find food, we do not know how a colony decides to recruit to that location and defend it.

Are some ants specialized to exploit certain foods depending upon where the foods are located? We investigated how microhabitat and food presentation influenced food monopoly by ants. We first assessed the impact of bait presentation and microhabitat upon monopoly. We then analyzed ant monopoly patterns considering the interaction between food type and microhabitat, in order to determine if monopoly occurred more frequently at specific combinations of food presentation and hábitat. Last, we used forager number as a measure of resource exploitation.

\section{MATERIALS AND METHODS}

This work was carried out at La Selva Biological Station, Sarapiquí Canton, Heredia Province, Costa Rica, in the dry season of 1996. La Selva is located in the Atlantic lowland wet tropical forest of northeastern Costa 
Rica, which receives ca. 4 meters of rainfall each year (McDade and Hartshorn 1994). La Selva has many species of resource-defending ants that recruit heavily to bait items (Kaspari 1993b, Byrne 1994, Tennant 1994).

We created a 0.5 hectare grid using the Geographic Information System (GIS) grid at La Selva; the plot was located within the GIS points $1100-1200 \cdot 800-850$, near the intersection of the Camino Cercano Circular and the Sendero Suroeste on the La Selva trail system. Sixty-six points were marked in a grid within the plot, with 10 meters separating each point along each axis. An earlier study at La Selva showed that 10 meters between baits maintained independent discoveries by colonies, because colony densities in the litter frequently exceeded 4 nests per $\mathrm{m}^{2}$, and ants rarely moved more than 1 meter from their nest to a bait (Kaspari 1996).

Environmental variables scored at each point permitted analyses of associations with the frequency of ants at baits. Microhabitat variables were selected to reflect biotic and abiotic factors that impact ant behavior. We measured leaf litter depth because diurnal variation in humidity is greater in shallow leaf litter (Kaspari1993a). Several observations of leaf litter ants interacting with other organisms supported the possiblity of interspecific.interactions. Thus, we determined the presence of a leafcutter ant (Atta cephalotes) trail and carton-nesting termites (Nastutitermes spp.) within $5 \mathrm{~m}$ of the bait, and plants of the family Melostomaceae, and palms within $1 \mathrm{~m}$ of the bait. Also, we measured the distance to the nearest treefalls, two nearest canopy trees, and the number of stems within $1 \mathrm{~m}$, which are structural variables that can influence where ants nest and forage. We tested for associations among environmental variables using: chi square tests among discrete variables, correlation matrices for continuous variables, and ANOVAs test for assocations between discrete and continuous variables. Because of the number of analyses, we performed a Bonferroni-Dunn correction on
ANOVAs to reduce the probability of a type I error. All environmental variables were independent of one another.

Bait consisted of oil-packed tuna. This is a standard bait and represents high-quality food to generalist ants (Perfecto 1994, Tennant, 1994). We drained excess oil before placement, so that ants would not be trapped in the bait. Baits were placed on $9.5 \mathrm{~cm}$ petri dishes. Two bait categories were used. These differed in position and size of individual food pieces, in order to elicit resource defense based on perceived differences among baits. Both "split" and "clumped" baits contained ca. 7 grams of tuna. Clumped baits contained $7 \mathrm{~g}$ of tuna placed in a single pile at the center of the dish, and split baits consisted of a $7 \mathrm{~g}$ piece of tuna split into four $1.75 \mathrm{~g}$ pieces placed at opposing edges of the dish. When the split baits were prepared, a thin layer of oil was spread over more than half of the area of the dish. The split baits covered a larger area, which may result in a greater likelihood for sharing because ants can exclusively use separate parts of the bait. We randomly assigned initial bait categories for each point on the 0.5 hectare grid. At least 2 days after the initial baiting period, each point was rebaited, such that every point was baited with both split and clumped bait types.

We waited two hours after bait placement before recording the presence and abundance of ants by species. Over the course of two hours in this forest, several species are likely to visit tuna baits at a given site, if is not raining (Tennant 1994). The total number of foraging ants at each bait was analysed to measure the impact of microhabitat and bait type upon the litterdwelling resource-defending ant community. Monopoly occurred when only one species was present at the bait at sampling. Dead workers were excluded from the data; we assumed they died as a result of interspecific combat or drowned in oil. The number of ants from each species attending a bait was estimated, and representative individuals were collected for identification using keys in Bolton (1994) and Longino and Hanson (1995). Several ants 
belonged to undescribed species. These were given identification letters for reference. We refer to one of the undescribed species as Pheidole simonsi Wilson and Brown; this is a provisional manuscript name. Its use here does not constitute description of a new species, and is not available in the sense of the International Code of Zoological Nomenclature.

To quantify bait monopoly, baits were placed in one of three categories: 1) no ants; 2) shared among two or more species, or 3) monopolized by a single species. We used the number of ants on a bait as an additional measure of resource exploitation; this is the "forager number." Resource monopoly indicates that only a single species is exploiting a food resource, while forager number indicates the level of resource exploitation.

\section{RESULTS}

We found 24 species at baits (Table 1). Because many of the ant species are uncommon within the forest, among our 66 sampling sites only five resource-defending species were observed several times. They were Pheidole $C$, Pheidole E, Pheidole simonsi Wilson and Brown (unpublished manuscript), and Solenopsis A, and Wasmannia auropunctata. These common species were used to determine differences in dominance at different bait categories and in different microhabitats.

Food presentation and monopoly by ant species: Monopoly, sharing, and the absence of ants differed between split vs. clumped baits (Table 2). However, the number of foragers recruited to split and clumped

All ants found 2 hours after bait placement. 24 species were present on 66 "split" and 66 "clumped" tuna baits within a 0.5 hectare old-growth forest plot. Ants observed by other authors as resource defenders ants are in bold (see introduction).

Species arriving at bait

Aphaenogaster araneoides

Atta cephalotes

Brachymyrmex sp. A

Brachymyrmex sp. B

Crematogaster sp. A

Ectatomma tuberculatum

Pheidole sp. A

Pheidole sp. B

Pheidole sp. C

Pheidole sp. D

Pheidole sp. E

Pheidole sp. F

Pheidole sp. $\mathrm{H}$

Pheidole simonsi

Pheidole sp. K

Pheidole sp. L

Pheidole sp. M

Pheidole sp. $\mathbf{N}$

Solenopsis (Fugax group) sp. A

Solenopsis (Fugax group) sp. B

Solenopsis (Fugax group) sp. C

Odontomachus sp. A

Paratrechina steinheili

Wasmannia auropunctata
Times at bait

17

1

5

1

1

2

2

1

16

8

22

5

1

7

4

1
Monopoly of bait

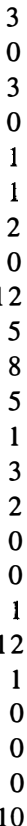


baits was equivalent. A mean of 24.4 (4.0 S.E.) ants arrived at clumped baits $(n=66)$, and 21.6 (3.2 S.E.) arrived at split baits (paired $\mathrm{t}$-test, $\mathrm{df}=64 ; \mathrm{t}=-0.70 ; \mathrm{p}=0.48, \mathrm{~ns}$ ). In most instances when split and clumped baits were shared by two or more ant species, the areas of the baiting platform utilized by each species where adjacent to one another, which suggests that these species had interacted with one another at the bait.

Of the five common resource-defending species, two differed in resource monopoly according to bait presentation (Table 3). W. auropunctata monopolized most split baits, but frequently shared clumped baits with other ants. On the other hand, Pheidole simonsi always monopolized clumped baits but shared split baits. When $W$. auropunctata did not monopolize split baits, the baits were shared with $P$. simonsi, suggesting that the two species have overlapping foraging preferences. Only one species, $P$. simonsi, had relatively more foragers at one of the bait types. This species recruited heavily to split baits, but not to clumped baits (Table 3). Interestingly, the clumped baits which contained few workers of $P$. simonsi were monopolized, while the split baits with many $P$. simonsi workers were shared. This suggests that the presence of interspecific competitors resulted in increased recruitment by $P$. simonsi.
TABLE 2

The frequency of absence, sharing, or monopoly by ants after 2 hours of tuna baiting.

The frequency of monoply, sharing, or absence of ants is not evenly distributed between split and clumped baits (Chi square test, $C^{2}=11.68 ; p=0.019$ ).

"Shared" indicates the presence of at least two species; "monopoly" indicates that only a single species persisted.

\section{Clumped baits}

$\begin{array}{llrrr}\text { split baits } & \text { No ants } & 5 & 0 & 6 \\ & \text { Shared } & 2 & 6 & 9 \\ & \text { Monopoly } & 3 & 13 & 22\end{array}$

Interactions between microhabitat and bait presentation: the effect on resource monopoly: Monopoly occurred more frequently than expected in two out of eight microhabitat variables. In both split and clumped baits, ants were more likely to monopolize baits where litter was deepest. Ants were more frequently absent at sites with shallow litter (Fig. 1). We performed G-tests comparing the relative frequency of monopoly, sharing, and the absence of ants at bait sites with the discrete microhabitat variables. The only significant relationship suggests a negative relationship between palms and the presence of foraging ants at split baits

TABLE 3

The impact of bait presentation on forager number and monopoly by common ant species.

We used a Mann Whittney U-test to compare number of recruited ants, and Fisher's exact test to compare monopoly frequency, to account for sample sizes. Standard errors are in parentheses.

* indicates a p value below 0.05 ;

** indicates a p-value less than 0.005 .

Species

$\begin{array}{lrrl}\text { Pheidole C } & 11.4(3.8) & 12(4.1) & \text { ns } \\ \text { Pheidole E } & 22.1(6.5) & 22.4(7.9) & \text { ns } \\ \text { Pheidole simonsi } & 28.8(5.9) & 3.7(1.7) & * \\ \text { Solenopsis A } & 9.2(4.1) & 7.2(1.6) & \text { ns } \\ \text { Wasmannia auropunctata } & 57.4(10.8) & 47.6(12.8) & \text { ns }\end{array}$

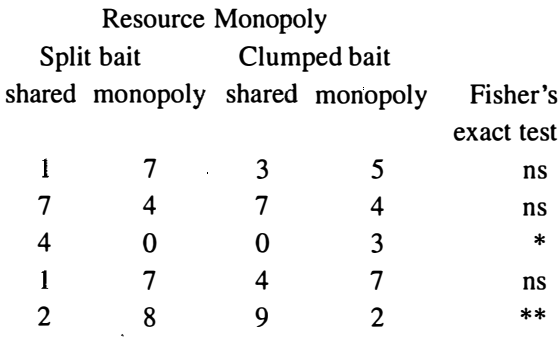




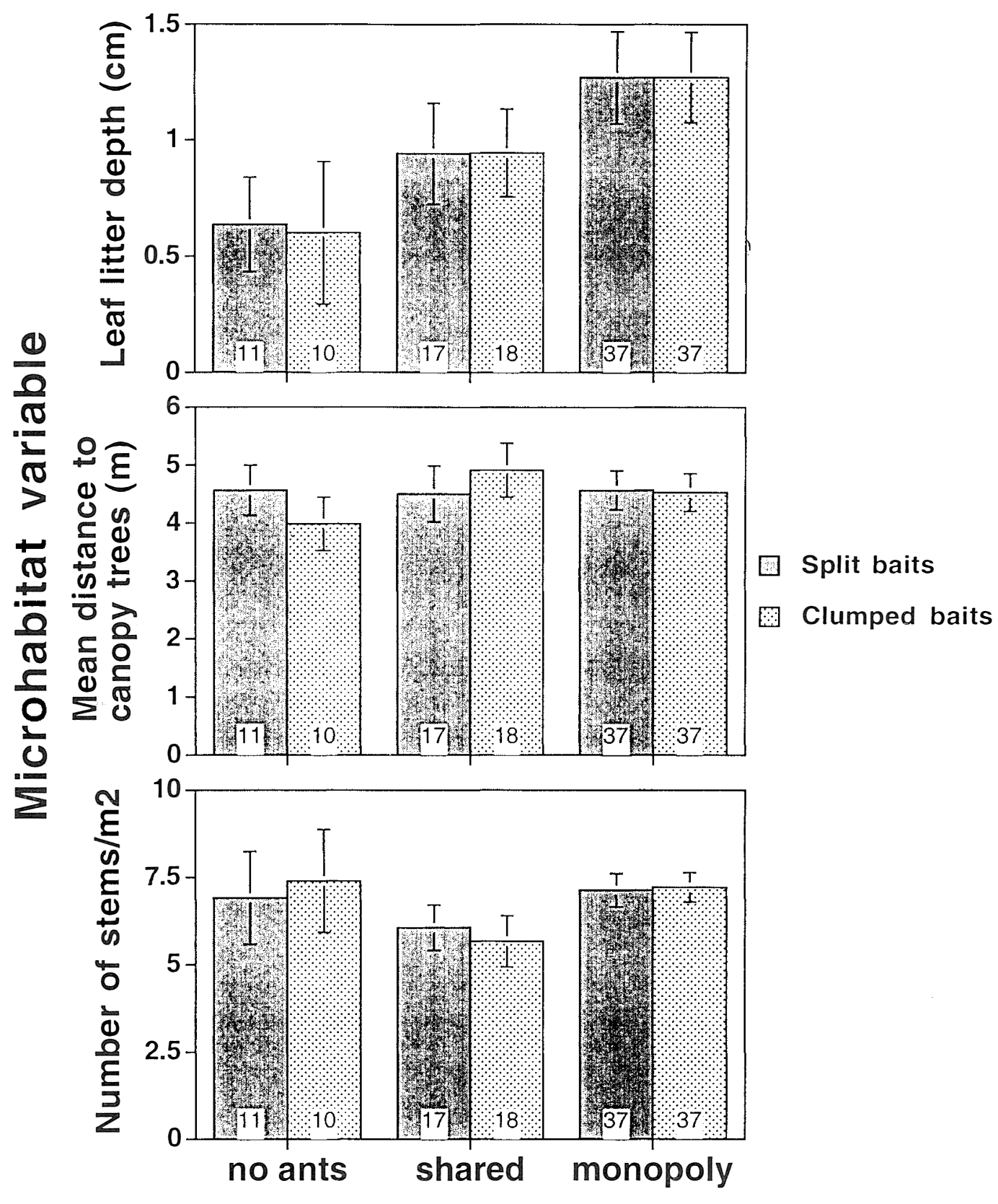

\section{Foraging ant response to baits}

Fig. 1. The impact of bait presentation and microhabitat on food monopoly. Error bars are standard errors; value labels indicate $\mathrm{n}$. Microhabitat variables are described in the methods. We used ANOVAs to compare the relationship between foraging ant response (monopoly, shared, absent) and microhabitat variables. Clumped and split baits combined, the leaf litter depth is variable with relation to foraging ant response (ANOVA, $\mathrm{F}=3.64 ; \mathrm{p}=.0029$ ); canopy tree distance (ANOVA, $\mathrm{F}=2.15$; $\mathrm{p}=0.12$ ) and the number of stems (ANOVA, $\mathrm{F}=0.28 ; \mathrm{p}=0.75$ ) are equivalent among ant responses. 


\section{TABLE 4}

Microhabitats associated with the number of recruited ants sorted by bait presentation. Because split and clumped baits were presented at the same locations, we used a repeated measures ANOVA to detect interactions between forager number and microhabitat. * indicates p-value is significant using the Bonferroni/Dunn test for multiple comparisons.

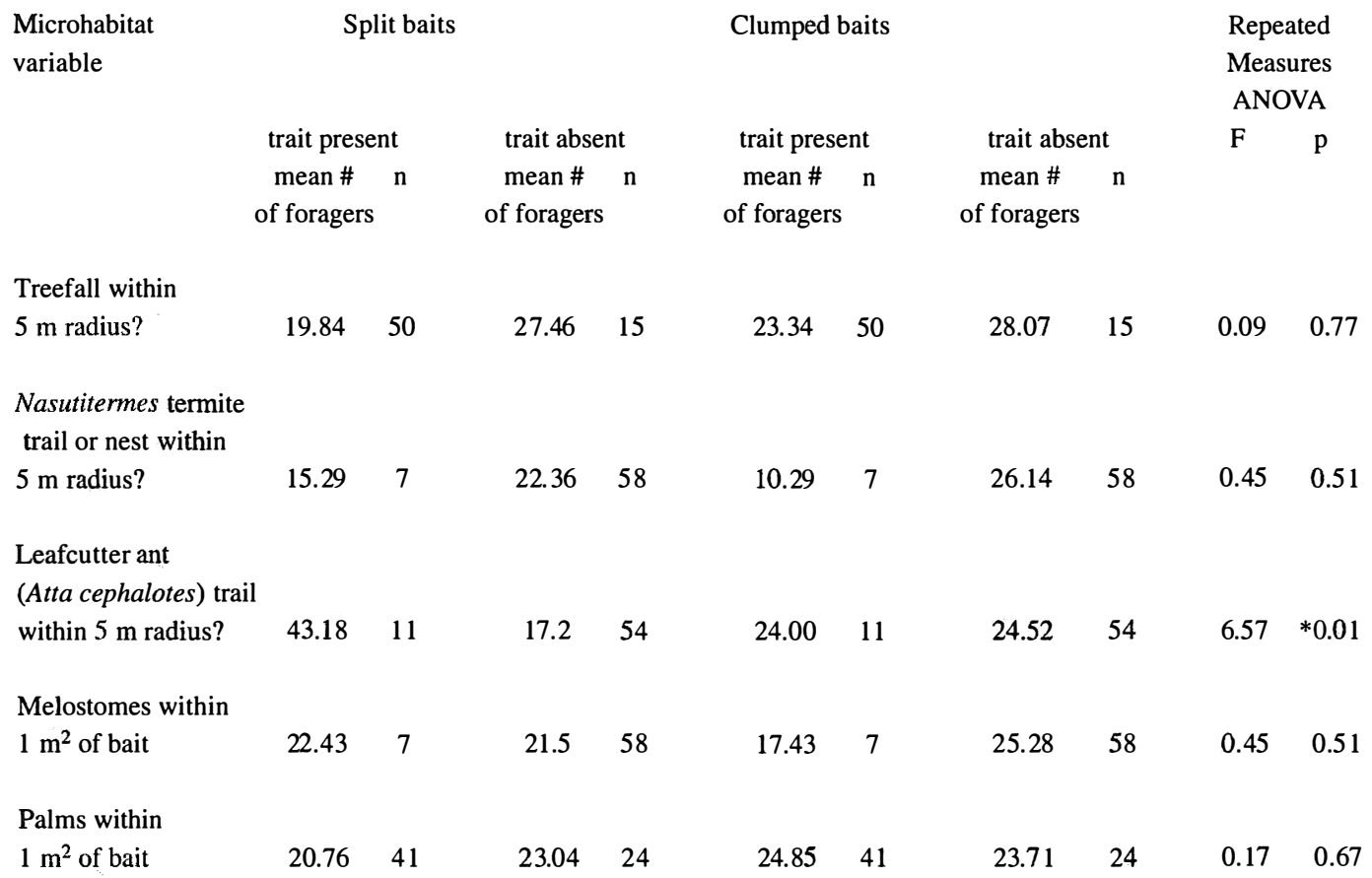

$(\mathrm{p}<0.05)$. Palms were present at only 55 percent of the bait sites; of 11 split baits without ants, palms were absent from only one site. In this forest, palms catch leaf litter from the canopy which often is inhabited by ants who nest in this litter (Tennant 1994, personal observation). The ants in these palms may not recruit to baits placed on the ground, but they may have impacted the foraging behavior of ground-dwelling resource-defending ants. This apparent deterrent effect of palms was not related to the number of stems. The density of stems showed no relationship to ant presence (t-test, $\mathrm{t}-1.094 ; \mathrm{p}=0.28$, ns).

Interactions between microhabitat and bait presentation: the effect on forager number: We used a repeated measures
ANOVA to test whether discrete microhabitat variables interacted with the level of ant recruitment depending upon the bait category (Table 4). Ants recruited more workers to split baits when close to leafcutter ant trails. We performed regression analyses to compare continouous microhabitat variables with forager recruitment at each bait. In Fig. 1 we present the mean numbers of foraging ants sorted by continuous microhabitat variables for each bait category. When ants foraged at clumped baits, forager number was correlated with canopy tree distance (Fig. 2). The impacts of microhabitat and bait type on the presence of resource-defending ants at baits are summarized in Table 5. 

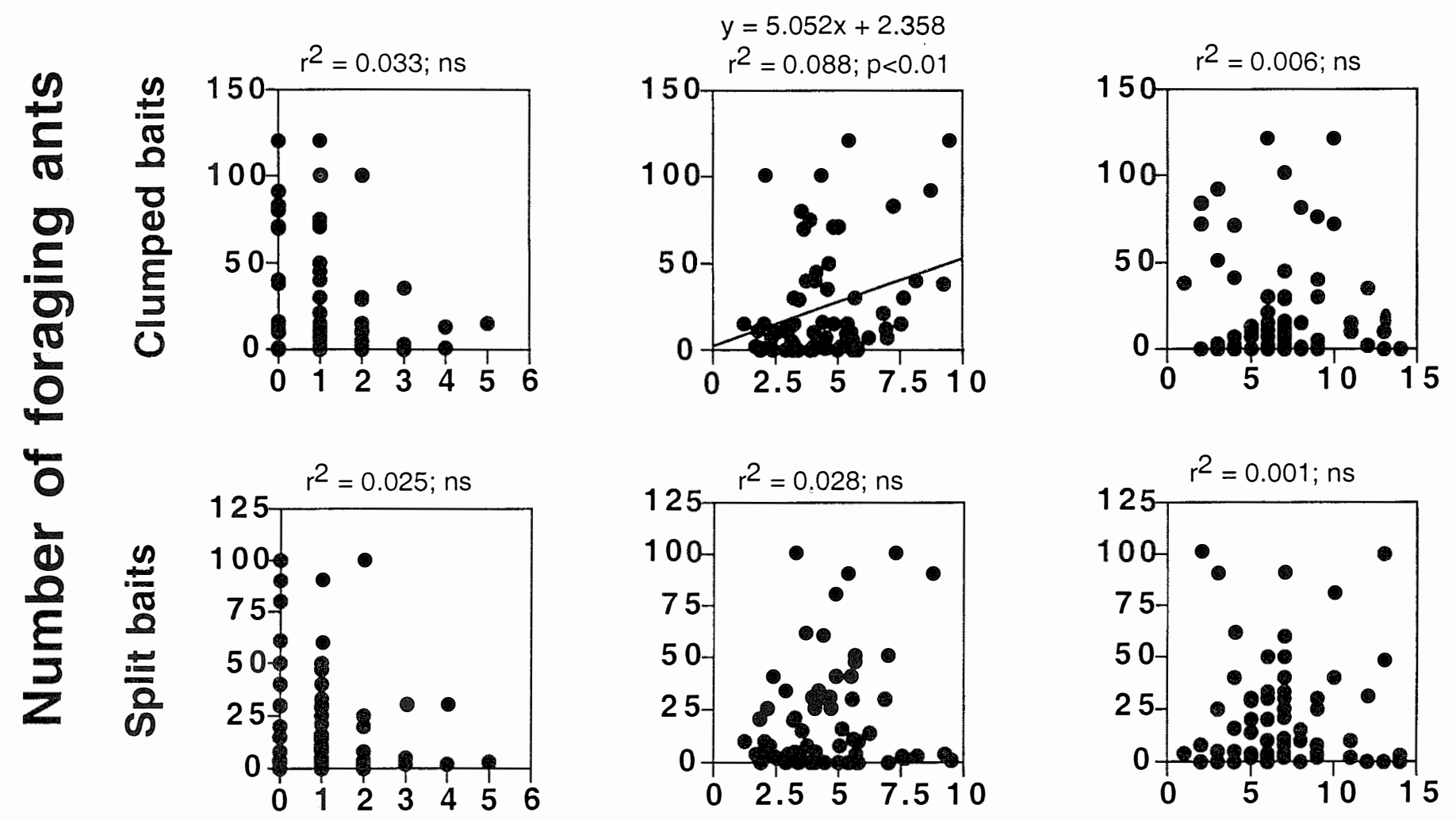

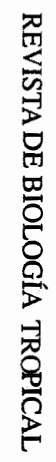

Leaf litter depth $(\mathrm{cm})$

Mean distance to canopy trees $(\mathrm{m})$

Number of stems $/ \mathrm{m}^{2}$

\section{Microhabitat variable}

Fig. 2. The impact of bait presentation and microhabitat on forager number. $\mathrm{N}$ for each scattergram is 66 . While leaf litter depth does not show a linear relationship, there is a significant difference in forager number between $0-2 \mathrm{~cm}$ depth and $3-5 \mathrm{~cm}$ depth in both split ( $\mathrm{t}-\mathrm{text}, \mathrm{p}<0.05)$ and clumped $(\mathrm{t}$-test, $\mathrm{p}<0.05)$ baits. Details about measurement of microhabitat variables are in the methods. 
TABLE 5

Summary of the effect of microhabitat and food presentation upon ant monopoly and forager number.

\begin{tabular}{|c|c|c|}
\hline Microhabitat variable & $\begin{array}{l}\text { Affects split or } \\
\text { clumped baits? }\end{array}$ & $\begin{array}{l}\text { Effect on ant monopoly } \\
\text { and forager number }\end{array}$ \\
\hline Leaf litter depth & split and clumped & $\begin{array}{l}\text { Monopoly occurs in deeper } \\
\text { litter; when no ants arrive, } \\
\text { litter is more shallow }\end{array}$ \\
\hline Mean distance to canopy trees & clumped & $\begin{array}{l}\text { Increased forager number far } \\
\text { away from canopy trees }\end{array}$ \\
\hline Number of stems & none & no effect \\
\hline Treefall & none & no effect \\
\hline Termites & none & no effect \\
\hline Leafcutter ants & split & $\begin{array}{l}\text { Increased forager number when } \\
\text { leafcutter trail is near }\end{array}$ \\
\hline Melostomes & none & no effect \\
\hline Palms & split & $\begin{array}{l}\text { When palms are near, ants are } \\
\text { more likely to be absent }\end{array}$ \\
\hline
\end{tabular}

\section{DISCUSSION}

Our analysis of the results draws out three major conclusions. First, the manner of food presentation influenced resource monopoly by two out of the five common species in this community, W. auropunctata and Pheidole simonsi. Second, monopoly by ants is more likely to occur in deep leaf litter, while food in shallow litter is least likely to be exploited by ants. Last, within some microhabitats, such as areas near leafcutter ant trails and canopy trees, the number of foragers depends upon the manner of food presentation. These three findings indicate that resource use by ground-foraging tropical ants is dependent upon the distribution of food resources as well as the specific location of food in the forest.

It is remarkable that a slight change in the manner of presentation of food will result in changes of resource monopoly by $W$. auropunctata and $P$. simonsi. One of the major components of the diet of these species is arthropods, evidenced by the remains found inside their nests. The foods presented to them in this study are within the size range of foods that they may encounter while foraging. As our bait types were variable in clump size and presentation, so is the natural avaiability of arthropod food in the forest (Janzen 1983). The variation in monopoly of our baits among ant species is likely to reflect the frequency of food monopoly by ants on naturally available foods.

The effect of leaf litter depth on monopoly by ants is probably tied to microclimatic effects on the foraging behavior of ants. The increased absence of ants on baits placed in shallow litter is consistent with Kaspari's (1993) finding that small-sized ants are more likely to dessicate in the less humid microclimate of shallow litter. The increased frequency of monopoly in deep leaf litter may be explained by either a more tolerable microclimate, as well as by the increased ant nest density within deep leaf litter (Kaspari 1996). Another explanation for more empty baits in shallow litter is that ants avoid foraging in shallow litter to exposure to predators and parasitoids.

Why do ants recruit more heavily to clumped baits far away from canopy trees? The canopy trees themselves probably do not 
direct biotic interactions with leaf litter ants. However, they affect the biotic and abiotic environment through sunflecks, litter composition, arboreal arthropod community, and branchfalls. Competition is extremely important in structuring ant communities. The most parsimonious explanation of the effect of canopy tree ants on ant abundance would correlate the distance to canopy trees with variables affecting ant competition. One of us currently is investigating the relationship between nest density and the distance to canopy trees; these may be negatively correlated with one another (McGlynn 1999). The impact of canopy trees upon leaf litter ants is complex. A simplistic explanation of the effect of canopy tree distance on ant recruitment, could be that areas of low nest density are far away from canopy trees, resulting in reduced local interspecific competition.

Why do resource-defending ants at split baits increase recruitment when the bait is located near leafcutter ants? Resource competition with leafcutting ants is unlikely, because of differences in food habits. However, leafcutter ants significantly impact the abiotic environment around them. Mature Atta nests contain millions of individuals (Hölldobler and Wilson 1990), and they are surrounded by large amounts of excavated dirt that are not covered by leaf litter. In the proximity of leafcutter ant nests, there is less leaf litter. Although there was an effect of leaf litter depth upon food monopoly, there was no effect upon forager number. Although we can rule out the direct effect of leaf litter as an explanation, the relationship between leafcutter trails and resource-defending ant recruitment remains for future study.

The difference in food monopoly based on bait presentation has implications for the other studies that depend upon baiting to study interspecific interactions in ants (some examples are: Delabie et al. 1985, Savolainen 1991, Perfecto, 1994, Torres, 1994, Human and Gordon 1996). Of the common species in our study, resource exploitation has been studied only in W. auropunctata. This species is a gen- eralist, feeding on extrafloral nectar as well as many resources on the ground. It vigorously defend baits against competing ant species (Clark et al. 1982, Lubin, 1985, Horvitz and Schemske 1990, Ulloa-Chacón and Cherix 1990, Williams and Whelan 1991, Tennant 1994, Jourdan 1997). Other research has shown that $W$. auropunctata can discriminate food based on protein and sugar content (Williams and Whelan 1992). Likewise, we know that with very small foods (less than 100 $\mathrm{mg}$ ); ants discriminate based on food size and food quality whether to recruit colony mates (Traniello 1983). With W. auropuntata, the increasing size of bait pieces is associated with a decrease in food monopoly. We found that $W$. auropunctata more frequently monopolizes a food when split into smaller pieces. At the same research site, Tennant (1994) found that W. auropunctata monopolized baits nearly $50 \%$ of the time when presented with a 4 gram tuna bait supplemented with a separate sugar solution. Considering the high level of monopoly at 1.75 gram pieces of food, and almost no monopoly at a large 7 gram piece of food, the addition of Tennant's data suggests that the frequency of monopoly is graded in association with food clump size. However, the spatial distribution of food may also be a significant factor in decisions to defend a food resource. Observations of food monopoly may be associated with long-term colony fitness; an ongoing study by one of us (McGlynn 1999) suggests that long-term addition of clumped food resources results in an increase of reproduction in a common Pheidole species.

The exploitation of food is determined by the availability of food outside the nest (Oster and Wilson 1978). Some features of microhabitat, such as litter depth, are directly associated with prey abundance (Levings and Windsor 1984). Because arthropods are not randomly located within leaf litter, ants searching for prey and dead insects probably search in specific microhabitats for specific types of food items. At least one Neotropical resourcedefending ant, Ectatomma ruidum, is capable of learning to feed at specialized sites and 
times associated with high prey availability (Schatz et al. 1994). Ants may select a microhabitat based on the type of resource that is frequent in that microhabitat. If ants enter certain microhabitats with a search image for a specific type of food resource, this may explain microhabitat asymmetries in dominance which occur only at one bait category.

\section{ACKNOWLEDGMENTS}

This research was supported by funding from the Mellon Foundation and the Organization for Tropical Studies to TPM, and from the New College Alumnae/i Association to SEK. We thank the Organization for Tropical Studies for use of the La Selva Biological Station resources; J. Beck, E. Britton, H. Hoyle, and M. Sherman contributed to field work; J. Longino assisted with ant identification and systematic treatment of undescribed species; M. Breed, D.A. Clark, D.B. Clark, and L. Alonso provided logistic and equipment support. We thank E. O. Wilson and the late Bill Brown for providing systematic data from their forthcoming revision of the Neotropical Pheidole. D. Armstrong, M. Breed, J. Bock, A. Chapman, and an anonymous reviewer shared comments on the manuscript.

\section{RESUMEN}

En los bosques húmedos de la Región Neotropical conviven varias especies de hormigas omívoras, defensoras de recursos alimenticios. Aunque el suelo del bosque es heterogéneo en microhábitat y alimento, se sabe poco sobre el impacto de ambos en las hormigas. Se investiga cómo influencian el tipo de alimento y el microhábitat la forma en que estas hormigas acaparan el alimento en un bosque húmedo tropical maduro (bajuras de Costa Rica). Se midieron ocho características de microhábitat en 66 puntos de una parcela de 0.5 ha. En cada punto se colocaron dos categorías de cebo (atún): "dividido" y "agrupado." Se midió el acaparamiento de cebo por especie y el número de hormigas por cebo. De cinco especies comunes, dos (Wasmannia auropunctata y Pheidole simonsi) monopolizaron con más frecuencia uno de los dos tipos de cebo, y una (P. simonsi) tuvo más individuos en los cebos divididos. La frecuencia de monopolio, comportamiento, y la ausencia de hormigas en punto dado en el bosque varió con el tipo de cebo. La frecuencia de acaparamiento se asoció con tipo de microhábitat en dos variables de microhábitat: profundidad de la hojarasca y palmas; la variación en distancia de bóvedas de árboles y caminos de hormigas cortadoras de hojas se asoció con cambios en el número de buscadores de alimento. En al menos dos especies la presentación del alimento afectó el acaparamiento; entre todas las hormigas estudiadas, los microhábitats y el tipo de alimento determinan en parte la frecuencia de acaparamiento y el número de individuso que llega al alimento. Estos resultados sugieren que la localización y presentación de alimento determina en parte cual especie de hormiga utilizará el recurso.

\section{REFERENCES}

Adams, E.S. \& J.F.A. Traniello. 1981. Chemical interference competition by Monomorium minimum (Hymenoptera: Formicidae) Oecologia 51: 265-270.

Andersen, A.N. 1992. Regulation of 'momentary' diversity by dominant species in exceptionally rich ant communities of the Australian seasonal tropics. Am. Nat. 140: 401-420.

Andersen, A.N. 1995. A classification of Australian ant communities, based on functional groups which parallel plant life-forms in relation to stress and disturbance. J. Biogeogr. 22: 15-29.

Andersen, A.N. 1997a. Functional groups and patterns of organization in North American ant communities: a comparison with Australia. J. Biogeogr. 24: 433-460.

Andersen, A.N. 1997b. Using ants as bioindicators: Multiscale issues in ant community ecology. Conservation Ecology [online] 1(1): 8. Available from the Internet. URL: http: //www.consecol.org/ vol1/iss 1/art8.

Andersen, A.N. \& A.D. Patel. 1994. Meat ants as dominant members of Australian ant communities: an experimental test of their influence on the foraging success and forager abundance of other species. Oecologia 98: 15-24.

Bernstein, R.A. 1975. Foraging strategies of ants in response to variable food density. Ecology 56: 213-229.

Bestelmeyer, B.T. \& J.A. Weins. 1996. The effects of land use on the structure of ground-foraging ant communities in the Argentine chaco. Ecol. Applic. 6: 1225-1240. 
Bolton, B. 1994. Identification guide to ant genera of the world. Harvard University, Cambridge, Massachusetts, USA.

Byrne, M.M. 1994. Ecology of twig-dwellings ants in a wet lowland tropical forest. Biotropica 26: 61-72

Clark, D.B., C. Guayasmín, O. Pazmiño, C. Donoso \& Y. Páez de Villacís. 1982. The tramp ant Wasmannia auropunctata: Autecology and effects on ant diversity and distribution on Santa Cruz Island, Galápagos. Biotropica 14: 196-207.

Davidson, D.W. 1977. Species diversity and community organization in desert seed-eating ants. Ecology 58: 711-724.

Davidson, D.W. 1978. Experimental tests of the optimal diet in two social insects. Behav. Ecol. Sociobiol. 4: 35-41.

Davidson, D.W. 1998. Resource discovery versus resource domination in ants: a functional mechanism for breaking the trade-off. Ecol. Ent. 23: 484-490.

de Biseau, J-C, Y. Quinet, L. Deffernez \& J.M. Pasteels. 1997. Explosive food recruitment as a competitive strategy in the ant Myrmica sabuleti (Hymenoptera: Formicidae). Insectes Sociaux 44: 59-73.

Delabie, J.H.C., I.C. Do Nascimento, P. Pacheco \& A.B Casimiro. 1995. Community structure of houseinfesting ants (Hymenoptera: Formicidae) in southern Bahia, Brazil. Florida Ent. 78: 264- 270.

Gordon, D.M. \& A.W. Kulig. 1996. Founding, foraging, and fighting: colony size and the spatial distribution of harvester ant nests. Ecology 77: 2393-2409.

Hölldobler B \& E.O. Wilson. 1990. The Ants. Belknap , Cambridge, Massachusetts, USA.

Horvitz, C.C. \& D.W. Schemske. 1990. Spatiotemporal variation in insect mutualists of a Neotrpical herb. Ecology 71: 1085-1097.

Human, K. \& D. Gordon D. 1996. Exploitative and interference competition between the Argentine ant and native ant species. Oecologia 105: 405-412.

Janzen, D.H. 1983. Insects: Introduction. Pages 619-644 in: D. Janzen, editor. Costa Rican Natural History. University of Chicago, Chicago, Illinois, USA.

Jourdan, H. 1997. Threats on Pacific islands: the spread of the tramp ant Wasmannia auropunctata (Hymenoptera: Formicidae). Pac. Cons. Biol. 3: 61-64.
Kaspari, M. 1993a. Body size and microclimate use in Neotropical granivorous ants. Oecologia 96: 500-507.

Kaspari, M. 1993b. Removal of seeds from Neotropical frugivore droppings: Ant responses to seed number. Oecologia 95: 81-88.

Kaspari, M. 1996. Testing resource-based models of patchiness in four Neotropical litter ant assemblages. Oikos 76: 443-454.

Levings, S.C. \& N.R. Franks. 1982. Patterns of nest dispersion in a tropical ground ant community. Ecology 63: 338-344.

Levings, S.C., D.M. Windsor. 1984. Litter moisture content as a determinant of litter arthropod distribution and abundance during the dry season on Barro Colorado Island, Panama. Biotropica 16: 125-131.

Longino, J.T. \& P.E. Hanson. 1995. The ants (Formicidae), p. 588-620 In Hanson, P.E. \& I.D. Gauld, editors. The Hymenoptera of Costa Rica,Oxford University, Oxford, UK.

Lubin, Y.D. 1985. Changes in the native fauna of the Galápagos Islands following invasion by the little red fire ant, Wasmannia auropunctata. Biol. J. Linn. Soc. 21: $229-242$

McDade, L.A. \& G.S. Hartshorn. 1994. La Selva Biological Station. Pages 6-14 in: L.A. McDade, K.S. Bawa, H.A. Hespenheide \& G.S. Hartshorn, editors. La Selva: Ecology and natural history of a neotropical rain forest. University of Chicago , Chicago, Illinois, USA.

McGlynn, T.P. 1999. The biogeography, behavior, and ecology of exotic ants. Ph.D. Thesis, University of Colorado, Boulder, Colorado, USA.

Oster, G.F. \& E.O. Wilson. 1978. Caste and ecology in the social insects. Princeton University, Princeton, New Jersey, USA.

Perfecto, I. 1994. Foraging behavior as a determinant of asymmetric competitive interaction between two ant species in a tropical agroecosystem. Oecologia 98 : 184-192.

Perfecto, I. \& J. Vandermeer. 1996. Microclimatic changes and the indirect loss of ant diversity in a tropical agroecosystem. Oecologia 108: 577-582.

Savolainen, R. 1991. Interference by wood ant influences size selection and retrieval rate of prey by Formica fusca. Behav. Ecol. Sociobiol. 28: 1-7. 
Savolainen, R. \& K. Vespalainen. 1988. A competition heirarchy among boreal ants: impact on resource partitioning and community structure. Oikos 51: 135-155.

Schatz, B., G. Beugnon \& J. Lachaud. 1994. Time-place learning by an invertebrate, the ant Ectatomma ruidum Roger. Animal Behaviour 48: 236-238.

Tennant, L.E. 1994. Ecology of a facultative ant-plant "mutualism." Ph.D. Thesis, Harvard University, Cambridge, Massachusetts, USA.

Torres, J.A. 1984. Niches and coexistence of ant communities in Puerto Rico: repeated patterns. Biotropica 16: 284-295.
Traniello, J.F.A. 1983. Social organization and foraging success in Lasius neoniger (Hymenoptera: Formicidae): behavioral and ecological aspects of recruitment communication. Oecologia 59: 94-100.

Ulloa-Chacon, P. \& D. Cherix 1990. The little fire ant Wasmannia auropunctata (R.) (Hymenoptera: Formicidae), p. 281-289 In R.K. Vander Meer, K. Jaffe \& A. Cedeno, editors, Applied myrmecology: a world perspective. Westview, Boulder, Colorado, USA.

Williams, D.F. \& P.M. Whelan. 1992. Bait attraction of the introduced pest ant, Wasmannia auropunctata (Hymenoptera: Formicidae) in the Galapagos Islands. J. Ent. Sci 27: 29-34. 